\title{
Cardiac Resynchronization Therapy: the Structural Response Is not Always Necessary
}

\author{
Terapia de Ressincronização Cardíaca: a Resposta Estrutural não se Faz \\ Sempre Necessária
}

\author{
Raphael Chiarini ${ }^{1} *$, Carlos Eduardo Duarte ${ }^{1}$, Thiago Rego da Silva ${ }^{1}$, André Brambilla \\ Sbaraini ${ }^{1}$, Guilherme Gaeski Passuello ${ }^{1}$, Luciene Dias de Jesus ${ }^{1}$, José Tarcisio Medeiros de \\ Vasconcelos ${ }^{1}$, Silas dos Santos Galvão Filho ${ }^{1}$
}

ORCID IDs

Chiarini R (D) https://orcid.org/0000-0001-8619-8393

Duarte CE (iD https://orcid.org/0000-0001-6671-0820

Silva TR (D) https://orcid.org/0000-0002-1973-427X

Sbaraini AB (D) https://orcid.org/0000-0002-5193-0860

\begin{abstract}
Up to $30-40 \%$ of patients undergoing cardiac resynchronization therapy (CRT) are described as nonresponders since the initial studies. This paradigm has inspired several modifications of the devices, electrodes and surgical technique in the implant. The definition of CRT response should be rethought, standardized, and ratings based on structural and/or clinical response should be proposed. The authors discuss a series of cases in which sustained clinical improvement was achieved despite structural worsening. Objective: To assess the profile of clinical responders to CRT who have worsened structurally. Method: It is a retrospective cohort of patients in outpatient follow-up from January 2012 to March 2017. We included 13 patients (2.7\%) out of a total of 476 submitted to CRT. Inclusion criteria were to present an improvement in functional class according to the New York Heart Association criteria (FC-NYHA) $\geq 1$ sustained for at least one year and absence of improvement or worsening of the structural parameters evaluated by transthoracic echocardiogram [ejection fraction (EF), diastolic diameter (LVDD) and systolic diameter (LVSD)]. The variables analyzed were age, gender, FC-NYHA, cardiopathy, echocardiographic and electrocardiographic parameters, medications in use, location of implanted electrodes, device programming, cardiary defibrillator therapies, and mortality. Statistical analysis was performed using non-parametric Wilcoxon and McNemar tests. Results: There were 13 patients, $92 \%$ male, mean age $60.9 \pm 9.2$ years and mean follow-up of $3.3 \pm 1.1$ years, $76 \%$ of CRT associated with implantable cardioverter defibrillator (CRT-D). In pre-implantation, $84.6 \%$ were in FC-NYHA III and then $61.5 \%$ were in FC-NYHA I $(p=0.001)$. The mean pre-implantation EF was $31.3 \pm 7.6 \%$ and $26.6 \pm 7.3$ $(p=0.002)$ in the last evaluation. The predominant heart disease was non-ischemic in $92.5 \%$, most of which were chagasic cardiomyopathy (CCM) (66\%). In the TRC-D group, no shock therapy was recorded in the period; there was one death in a patient with ischemic cardiomyopathy (IC) for the septic shock of pulmonary focus after 2.2 years of follow-up. The mean QRS was $189.9 \pm 23.1$ ms to 157.9 \pm 35.2 after CRT ( $p=0.032$ ). There was no significant change in pre-and postimplant medications during follow-up. Conclusion: The absence of structural improvement should not be considered therapeutic failure, since CRT seeks to modify the electrical activation, and may be related to better performance and decrease of symptoms, even in evolutionary heart diseases.
\end{abstract}

KEYWORDS: Cardiac resynchronization therapy; Cardiac insufficiency; Echocardiography; Cardiac electrophysiology.

\author{
Passuello GG (iD https://orcid.org/0000-0002-5547-3484 \\ Jesus LD (iD https://orcid.org/0000-0003-0434-2756 \\ Vasconcelos JTM (iD https://orcid.org/0000-0002-5152-2648 \\ Galvão Filho SS (iD https://orcid.org/0000-0001-5236164X
}

\section{RESUMO}

Até 30-40\% dos pacientes submetidos à terapia de ressincronização cardíaca (TRC) são descritos como não respondedores desde os trabalhos iniciais. Esse paradigma tem inspirado diversas modificações dos dispositivos, eletrodos e técnica cirúrgica no implante. A definição de resposta à TRC deverá ser repensada, padronizada, e classificações pautadas na resposta estrutural e/ou clínica devem ser propostas. Os autores discutem uma série de casos em que se obteve melhora clínica sustentada a despeito da piora estrutural. Objetivo: Avaliar o perfil dos pacientes respondedores clínicos à TRC que pioraram estruturalmente. Método: Trata-se de coorte retrospectiva de pacientes em seguimento ambulatorial de janeiro de 2012 a março de 2017. Foram incluídos 13 pacientes (2,7\%) de um total de 476 submetidos à TRC. Os critérios de inclusão foram apresentar melhora da classe funcional pelos critérios da New York Heart Association (CF-NYHA) $\geq 1$ sustentada por pelo menos um ano e ausência de melhora ou com piora dos parâmetros estruturais avaliados pelo ecocardiograma transtorácico [fração de ejeção (FE), diâmetro diastólico (DDVE) e diâmetro sistólico (DSVE)]. As variáveis analisadas foram idade, gênero, CF-NYHA, cardiopatia, parâmetros ecocardiográficos e eletrocardiográficos, medicações em uso, localização do implante dos eletrodos, programação do dispositivo, terapias do cardiodesfibrilador e mortalidade. A análise estatística foi realizada por meio dos testes não paramétricos de Wilcoxon e McNemar. Resultado: Foram 13 pacientes, sendo 92\% do sexo masculino, idade média de 60,9 \pm 9,2 anos e seguimento médio de 3,3 $\pm 1,1$ anos, 76\% de TRC associada a cardiodesfibrilador implantável (TRC-D). No pré-implante, 84,6\% encontravam-se em CF-NYHA III e, em seguida, 61,5\% estavam em CF-NYHA I $(p=0,001)$. A FE média pré-implante foi de $31,3 \pm 7,6 \%$ e 26,6 $\pm 7,3(p=0,002)$ na última avaliação. A cardiopatia predominante foi a não isquêmica em 92,5\%, sendo a maioria cardiomiopatia chagásica (CMC) (66\%). No grupo TRC-D, não foi registrada terapia de choque no período; houve um óbito em um paciente com cardiomiopatia isquêmica (CMI) por choque séptico de foco pulmonar após 2,2 anos de seguimento. O QRS médio foi de 189,9 $\pm 23,1$ ms para 157,9 \pm 35,2 após $\operatorname{TRC}(p=0,032)$. Não houve mudança significativa nas medicações administradas pré- e pós-implante durante o seguimento. Conclusão: A ausência de melhora estrutural não deve ser considerada falha terapêutica, pois a TRC procura modificar a ativação elétrica, podendo estar relacionada a melhor desempenho e diminuição dos sintomas, mesmo em cardiopatias evolutivas.

PALAVRAS-CHAVE: Terapia de ressincronização cardíaca; Insuficiência cardíaca; Ecocardiografia; Eletrofisiologia cardíaca.

1.Centro Avançado de Ritmologia e Eletrofisiologia - São Paulo/SP - Brazil.

*Correspondence author: raphaelchiarini@yahoo.com.br

Received: 11 Mar 2019| Accepted: 09 May 2019

Section Editor: J. Tarcísio Medeiros de Vasconcelos 


\section{INTRODUCTION}

Cardiac pacing began to be thought of as adjuvant therapy in the treatment of cardiac insufficiency (CI) refractory to pharmacological treatment in the mid-1990s. The theoretical and experimental basis of this application is the correction of delayed left ventricular (LV) contraction in patients with IC that present complete left bundle branch block (LBBB). In these cases, with the advent of imaging exams such as echocardiography, it can be confirmed that, in addition to the delay in electrical activation, there is mechanical dyssynchrony of the ventricle, decreasing cardiac efficiency, and may promote cardiac remodeling in the short and long term. Important randomized studies supported implant guidelines adopted in Brazil and by the leading scientific societies in the United States and Europe (American College of Cardiology (ACC), American Heart Association (AHA), Heart Rhythm Society (HRS) and European Society of Cardiology (ESC)], being recommended as a recommendation class I and level A evidence of cardiac resynchronization therapy (CRT) for NYHA II and III patients, QRS duration $\geq 150 \mathrm{~ms}$ and LBBB, provided that with optimized drug therapy, sinus rhythm and EF $\leq 35 \% 8-11$. Although there are no important randomized studies, it is now possible to identify other groups of patients with a high probability of positive response to CRT, setting guidelines as indication class I or II with a level of evidence B8-11. Despite the technical advances of devices, electrodes, implant surgery, and development of complementary methods, more recent studies still classify about $30 \%$ of patients as non-responders to CRT despite the lack of consensus in the definition of CRT response ${ }^{1-8}$. The present study analyzed a retrospective cohort of patients submitted to CRT, evaluating the profile of clinical responders to therapy, seeking to identify factors associated with the mechanism of action that results in clinical improvement without the presence of structural improvement.

\section{METHODS}

Retrospective study of a cohort of follow-up patients at the Advanced Center of Ritology and Electrophysiology (Centro Avançado de Ritmologia e EletrofisiologiaCARE), in the state of São Paulo, submitted to the CRT from January 2012 to March 2017.
Age, gender, FC-NYHA, cardiopathy, echocardiographic parameters, and pre and post-CRT electrocardiographic parameters, medications in use, electrode implant localization, device programming, cardidefibrillator therapies, and mortality were analyzed. The criteria for an indication of CRT and outpatient follow-up obeyed the institutional protocol that follows the Brazilian Guidelines for Implantable Electronic Cardiac Devices.

The criterion used to define exclusively a clinical response to CRT was: improvement of the SF by NYHA criteria $\geq 1$ sustained for a minimum period of 12 months after CRT, without improvement or worsening of the structural parameters in the transthoracic echocardiogram.

Exclusion criteria were any increase in left ventricular ejection fraction (EF) and/or reduction of diastolic and/ or final systolic diameters evaluated by transthoracic echocardiography or unsupported clinical improvement for a minimum period of 12 months.

\section{Statistical analysis}

Continuous variables were expressed in means \pm standard deviation (SD) and categorical variables in percentages. Statistical analysis was performed using non-parametric Wilcoxon and McNemar tests. The representation was made by the mean, $\mathrm{SD}$ and quartiles (Tables 1, 2 and 3).

\section{RESULTS}

A total of 476 sequential charts of patients submitted to CRT-related surgical intervention from January 2012 to March 2017 were selected. Thirteen patients (2.7\%) met the inclusion criteria, most were male (92\%), with a mean age of $60.9 \pm 9.2$ years. Before implantation, FC-NYHA was III in $84.6 \%$, IV in $7.6 \%$ and II in 7.6\%; Mean EF of the LV was $31.3 \pm 7.9 \%$, the mean systolic diameter (LVSD) was $53.2 \pm 5.1 \mathrm{~mm}$ and the mean diastolic diameter (LVDD) was $65.5 \pm 5.9$. Baseline heart disease was distributed in: Chagas cardiomyopathy (CCC) in 61\%; hypertensive (HiCM) in 15\%; dilated (DCM) in $8 \%$; ischemic (ICM) in 8\%; and hypertrophic (HCM) in $8 \%$. Pre-implantation sinus rhythm was present in $76 \%$ of the patients, with a mean QRS of $189.9 \pm 29.1 \mathrm{~ms}$, with an LBBB pattern being identified in $61.5 \%$, of which $25 \%$ were associated with axis deviation for left. Right 
bundle branch block (RBBB) was evident in 38.8\%, 60\% of which were associated with an anterosuperior divisional block (ADB) and $20 \%$ associated with a posteroinferior divisional block (PIDB). The median pre-implant axis was between -90 to $0^{\circ}$ in $53 \%$. Most were using pharmacological therapy at optimized doses pre- and post-implant of the device. There were no significant changes in the

Table 1. Medications.

\begin{tabular}{|c|c|c|c|}
\hline \multirow{2}{*}{ Medication } & Pre-TRC & Post-TRC & \multirow{2}{*}{ - p-value } \\
\hline & \multicolumn{2}{|c|}{$\mathrm{n}(\%)$} & \\
\hline $\begin{array}{l}\text { Angiotensin } \\
\text { converting enzyme } \\
\text { inhibitors }\end{array}$ & $6(46.2)$ & $7(53.8)$ & 0.317 \\
\hline $\begin{array}{l}\text { Angiotensin receptor } \\
\text { blockers }\end{array}$ & $5(38.5)$ & $4(30.8)$ & 0.317 \\
\hline Furosemide & $8(61.5)$ & $7(53.8)$ & 0.564 \\
\hline Beta blocker & $13(100.0)$ & $13(100.0)$ & - \\
\hline Spironolactone & $10(76.9)$ & $9(69.2)$ & 0.564 \\
\hline Amiodarone & $9(69.2)$ & $10(76.9)$ & 0.564 \\
\hline Propafenone & $1(7.7)$ & $0(0.0)$ & 1.000 \\
\hline Nitrate & $1(7.7)$ & $1(7.7)$ & - \\
\hline Digoxin & $2(15.4)$ & $2(15.4)$ & - \\
\hline Acetylsalicylic acid & $4(30.8)$ & $4(30.8)$ & - \\
\hline Oral anticoagulant & $5(38.5)$ & $3(23.1)$ & 0.157 \\
\hline Statin & $8(61.5)$ & $8(61.5)$ & - \\
\hline
\end{tabular}

disease-modifying drugs, such as beta-blockers, angiotensin converting enzyme inhibitor (ACEI), or potassium-sparing angiotensin II receptor blocker (ARB) and diuretic with pre-and post-CRT 100 and 100\%, 84.6 and 84.6\%, 76.9 and $69.2 \%$, respectively. The loop diuretic rate remained at $54 \%$ in the pre- and post-implant periods (Table 1). After CRT, with a mean follow-up of $3.3 \pm 1.1$ years, there was the improvement of at least 1 point in NYHA-FC in $100 \%$ of the patients $(\mathrm{p}=0.001)$ and in $62 \%$ there was the improvement of 2 points. The mean EF was $31.3 \pm 7.9 \%$ in the pre-implant period to $26.6 \pm 7.6 \%$ post-implant $(\mathrm{p}=0.002)$. There were increased diameters after CRT: mean LVSD $63.2 \pm 6.8 \mathrm{~mm}(\mathrm{p}=0.018)$ and mean LVDD $70.3 \pm 7.5 \mathrm{~mm}(\mathrm{p}=0.015)$.

The devices were programmed in $76 \%$ in the DDD mode, being 53\% multipoint, with an average atrioventricular (AV) interval of $214 \mathrm{~ms}$. The biventricular

Table 3. Electrical axis of the maximum SâQRS in quadrants.

\begin{tabular}{|c|c|c|c|}
\hline \multirow{2}{*}{ SâQRS } & Pre-TRC & Post-TRC & \multirow{2}{*}{$p$-value } \\
\hline & \multicolumn{2}{|c|}{ n (\%) } & \\
\hline I $\left(-90\right.$ to $\left.0^{0}\right)$ & $7(53.8)$ & $1(7.7)$ & \multirow{4}{*}{0.027} \\
\hline II $\left(0\right.$ to $\left.+90^{\circ}\right)$ & $2(15.4)$ & $4(30.8)$ & \\
\hline III (+90 to $\left.180^{\circ}\right)$ & $3(23.1)$ & $6(46.2)$ & \\
\hline IV $\left(180\right.$ to $\left.-90^{\circ}\right)$ & $1(7.7)$ & $2(15.4)$ & \\
\hline
\end{tabular}

Table 2. Comparison of echocardiographic and electrocardiographic parameters before and after cardiac resynchronization (CRT).

\begin{tabular}{|c|c|c|c|c|c|c|c|c|c|c|}
\hline Variiable & Moment & $\mathrm{n}$ & Mean & DP & Minimum & Maximum & P25 & Medium & P75 & $\mathrm{p}$-value \\
\hline \multirow{2}{*}{ Aorta (mm) } & Pre-TRC & 10 & 32.30 & 2.87 & 27.00 & 37.00 & 30.75 & 32.00 & 34.50 & 0.471 \\
\hline & Post-TRC & 10 & 31.60 & 2.80 & 26.00 & 36.00 & 29.75 & 32.00 & 33.25 & \\
\hline \multirow{2}{*}{ Left atrium (mm) } & Pre-TRC & 12 & 45.75 & 10.20 & 32.00 & 64.00 & 35.75 & 46.00 & 55.00 & 0.167 \\
\hline & Post-TRC & 12 & 48.00 & 9.83 & 35.00 & 70.00 & 39.00 & 46.00 & 54.50 & \\
\hline \multirow{2}{*}{$\begin{array}{l}\text { Left ventricular systolic } \\
\text { diameter) }\end{array}$} & Pre-TRC & 7 & 53.29 & 5.19 & 46.00 & 59.00 & 49.00 & 55.00 & 58.00 & 0.018 \\
\hline & Post-TRC & 7 & 63.29 & 6.82 & 50.00 & 72.00 & 61.00 & 64.00 & 67.00 & \\
\hline \multirow{2}{*}{$\begin{array}{l}\text { Left ventricular diastolic } \\
\text { dimension }(\mathrm{mm})\end{array}$} & Pre-TRC & 13 & 65.54 & 5.97 & 58.00 & 81.00 & 61.00 & 65.00 & 68.50 & 0.015 \\
\hline & Post-TRC & 13 & 70.38 & 7.50 & 54.00 & 84.00 & 67.00 & 70.00 & 76.50 & \\
\hline \multirow{2}{*}{ Septum (mm) } & Pre-TRC & 11 & 8.18 & 1.08 & 7.00 & 10.00 & 7.00 & 8.00 & 9.00 & 0.732 \\
\hline & Post-TRC & 11 & 8.36 & 1.75 & 6.00 & 11.00 & 7.00 & 8.00 & 10.00 & \\
\hline \multirow{2}{*}{ Posterior wall (mm) } & Pre-TRC & 11 & 8.18 & 1.17 & 7.00 & 10.00 & 7.00 & 8.00 & 9.00 & 0.726 \\
\hline & Post-TRC & 11 & 8.00 & 1.34 & 6.00 & 11.00 & 7.00 & 8.00 & 9.00 & \\
\hline \multirow{2}{*}{$\begin{array}{l}\text { Left ventricular ejection } \\
\text { fraction (\%) }\end{array}$} & Pre-TRC & 13 & 31.31 & 7.93 & 18.00 & 46.00 & 28.00 & 32.00 & 37.00 & 0.002 \\
\hline & Post-TRC & 13 & 26.62 & 7.63 & 15.00 & 41.00 & 19.50 & 28.00 & 31.00 & \\
\hline \multirow{2}{*}{ Right ventricle (mm) } & Pre-TRC & 3 & 32.33 & 0.58 & 32.00 & 33.00 & 32.00 & 32.00 & 33.00 & - \\
\hline & Post-TRC & 3 & 29.00 & 8.19 & 22.00 & 38.00 & 22.00 & 27.00 & 38.00 & \\
\hline \multirow{2}{*}{ QRS (ms) } & Pre-TRC & 13 & 189.92 & 29.10 & 150.00 & 240.00 & 160.00 & 190.00 & 204.50 & 0.032 \\
\hline & Post-TRC & 13 & 157.92 & 35.21 & 80.00 & 200.00 & 127.50 & 160.00 & 180.00 & \\
\hline
\end{tabular}


pacing rate was $98.7 \%$, with the $L V-R V$ pacing pattern 61.5\%, RV-LV 23\%, and simultaneous 15.5\%. The QRS under biventricular pacing was $187.1 \pm 25.9 \mathrm{~ms}$ with $\mathrm{ADB}$ in $7 \%$ and PIDB in $46 \%$, mean axis under stimulation between +90 and $+180^{\circ}$ in $43 \%$ and between 0 and $+90^{\circ}$ in $30 \%$. Regarding the position of the electrodes, the right ventricle was superior to the septal-basal, superseptal-medial and mid-septal-apical positions in 38, 23 and $38 \%$ of the implants, respectively. The LV electrode in mid-latero-basal position in $23 \%$, supero-latero-basal 15\%; medial-latero-medial 15\% infero-latero-apical 15\%, infero-latero-medial $15 \%$ and superior-antero-basal $15 \%$. There were no records of cardiac defibrillator shock therapies. There was one death in a patient with IMC related to pulmonary focus septic shock with 2.2 years of CRT (Tables 1 and 2).

\section{DISCUSSION}

This study discusses the standardization of CRT response criteria and proposes analysis from both the structural and clinical perspectives, questioning the real need to restrict the indication of CRT to those who have established predictors of structural response, such as the presence of $\mathrm{LBBB}$ and $\mathrm{QRS}>150 \mathrm{~ms}$ in patients with DCM.

It should be remembered that in the onset of CRT, with the study MUSTIC ${ }^{15}$ was analyzed exactly that the functional capacity was improved, the quality of life and the patientss preference for the mode of stimulation, with $\mathrm{LV}$ stimulation bound or not. Restricting CRT to the point of structural improvement would deny its greatest benefit to those with evolutionary structural cardiomyopathy.

Question: Can driving disorders be the cause of $\mathrm{CI}$ or just an aggravating factor? In the MADIT-CRT study ${ }^{25}$, in women with mild IC symptoms, female gender, absence of infarction, LBBB, QRS> $150 \mathrm{~ms}$, body mass index $(\mathrm{BMI})<30 \mathrm{~kg} / \mathrm{m} 2$ and reduced left atrial volume were predictors of normalization of parameters and clinical improvement before CRT (super-responders). In these cases CRT is very likely to act on the pathophysiology of ventricular dysfunction, restoring normalization.

In this context, we discussed whether the clear change in the direction of activation (Table 3 ) and the search for correction of conduction disturbance were determinants of improvement in clinical performance even in those whose etiology was of evolutionary cardiomyopathies, such as Chagas> disease.

The major criticism of these results is the deficiency of other parametric clinical evaluations. On MUSTIC ${ }^{15}$, in addition to FC-NYHA, the 6-minute walk test, the peak $\mathrm{O} 2$ consumption (VO2 peak), and the Minnesota quality of life score were analyzed. Clinical evaluation of this study was limited to FC-NYHA. Regarding echocardiographic references, a deficiency is present in the evaluation of pre-and post-implant mitral regurgitation, since it could be a determinant of response. It is believed that the reduction of mitral regurgitation before CRT may lead to increased pressure load in the LV, resulting in increased diameters with worsening of global EF, but generating a greater anterograde flow through the LV exit pathway, resulting in clinical improvement. The actual understanding of the clinical improvement of this group of patients should encourage prospective studies to study this effect.

\section{CONCLUSION}

The absence of structural improvement should not be considered therapeutic failure. Electrical dyssynchrony can lead to changes in the sense of activation, causing slower and disharmonious contractions, resulting in hemodynamic performance deficit. The CRT seeks to accelerate and harmonize electrical activation, correcting driving disorders that worsen cardiac performance, and may promote clinical and/or structural improvement.

\section{AUTHORS' CONTRIBUTION}

Conceptualization, Chiarini R; Duarte CE; Vasconcelos JTM de; Galvão Filho SS. Methodology, Chiarini R; Duarte CE; Vasconcelos JTM de; Galvão Filho SS; Research, Chiarini R; Duarte CE; Silva TR da; Sbaraini AB; Passuello GG; Jesus LD de; Vasconcelos JTM de; Galvão Filho SS; Writing - First version, Chiarini R; Passuello GG; Silva TR da; Writing - Review \& Editing, Chiarini R; Duarte CE; Acquisition of Financing, Duarte CE; Resources, Chiarini R; Duarte CE; Supervision, Duarte CE 


\section{REFERENCES}

1. Fuganti C], Melo CS, Moraes Jr AV, Pachon-Mateos JC, Pereira WL, Galvão Filho SS, et al. Diretriz: - Terapia de ressincronização cardíaca. Relampa. 2015;28(Suppl 2):S26-S40.

2. Chung ES, Leon AR, Tavazzi L, Sun JP, Nihoyannopoulos P, Merlino J, et al. Results of the predictors of response to CRT (PROSPECT) trial. Circulation. 2008;117(20):2608-16. https://doi. org/10.1161/CIRCULATIONAHA.107.743120

3. Rocha EA, Moreira FT, Quidute AR, Abreu JS, Lima WO, Rodrigues $C R$, et al. Quem são os super-respondedores à terapia de ressincronização cardíaca? Int J Cardiovasc Sci. 2017;30(1):61-9. https://doi.org/10.5935/2359-4802.20170020

4. Tracy CM, Epstein AE, Darbar D, Dimarco JP, Dunbar SB, Estes NA 3rd, et al. 2012 ACCF/AHA/HRS focused update of the 2008 guidelines for device-based therapy of cardiac rhythm abnormalities: a report of the American College of Cardiology Foundation/American Heart Association Task Force on Practice Guidelines. J Am Coll Cardiol. 2012;60(14):1297-313. https://doi. org/10.1161/CIR.0b013e3182618569

5. Yu CM, Bleeker GB, Fung JW, Schalij MJ, Zhang Q, van der Wall $E E_{\text {, et }}$ al. Left ventricular reverse remodeling but not clinical improvement predicts long-term survival after cardiac resynchronization therapy. Circulation. 2005;112(11):1580-6. https://doi.org/10.1161/CIRCULATIONAHA.105.538272

6. Rao RK, Kumar UN, Schafer J, Viloria E, De Lurgio D, Foster E. Reduced ventricular volumes and improved systolic function with cardiac resynchronization therapy: a randomized trial comparing simultaneous biventricular pacing sequential biventricular pacing, and left ventricular pacing. Circulation. 2007;115(16):2136-44. https://doi.org/10.1161/ CIRCULATIONAHA.106.634444

7. Leclercq C, Gras D, Le Helloco A, Nicol L, Daubert C. Hemodynamic importance of preserving the normal sequence of ventricular activation in permanent cardiac pacing. Am Heart J 1995;129:1133-41. https://doi.org/10.1016/00028703(95)90394-1

8. TracyCM, EpsteinAE, DarbarD, DiMarcoJP, DunbarSB, EstesNAM. 2012 ACCF/AHA/HRS focused update of the 2008 guidelines for device-based therapy of cardiac rhythm abnormalities. A report of the American College of Cardiology Foundation/American Heart Association Task Force on Practice Guidelines and the Heart Rhythm Society. Circulation. 2012;126:1784-1800. https:// doi.org/10.1161/CIR.0b013e3182618569

9. Comitê Coordenador da Diretriz de Insuficiência Cardíaca. Diretriz brasileira de insuficiência cardíaca crônica e aguda. Arq Bras Cardiol. 2018;111(3):436-539. https://doi.org/10.5935/ abc.20180190

10. The Task Force on cardiac pacing and resynchronization therapy of the European Society of Cardiology (ESC). ESC Guidelines on cardiac pacing and cardiac resynchronization therapy. Eur Heart J. 2013;34:2281-2329. https://doi.org/10.1093/eurheartj/eht150

11. The Task Force for the diagnosis and treatment of acute and chronic heart failure of the European Society of Cardiology (ESC). ESC Guidelines for the diagnosis and treatment of acute and chronic heart failure. Eur Heart J. 2016;37:2129-2200. https:// doi.org/10.1093/eurheartj/ehw128.
12. Martinelli Filho M, Peixoto GL, Siqueira SF, Martins SAM, Nishioka SAD, Costa $R$, et al. Terapia de ressincronização cardíaca na cardiomiopatia chagásica crônica: boa resposta clínica e pior prognóstico. Relampa. 2013;26(1):33-8.

13. Garillo R, Salgado Melo C, Pachón Mateos CTC, Silva Jr. O, Leite GMS, Carvalho ElJ. Pacientes não responsivos à terapia de ressincronização cardíaca. Relampa. 2007;20(3):167-74.

14. Menezes Junior AS, Stival WN, Lopes ISP. Indicações da terapia de ressincronização cardíaca: discussão baseada em estudos recentes. Relampa. 2014;27(1):34-9.

15. Linde C, Leclercq C, Rex S, Garrigue S, Lavergne T, Cazeau $\mathrm{S}$, et al. Long-term benefits of BiV pacing in heart failure. JACC. 2002;40(1):111-8. https://doi.org/10.1016/S07351097(02)01932-0

16. Linde C, Ellenbogen $\mathrm{K}$, McAlister FA. CRT: clinical trials, guidelines, and target populations. Heart Rhythm. 2012;9(Suppl 8):S3-S13. https://doi.org/10.1016/j.hrthm.2012.04.026

17. Rocha EA. Analysis of cardiac dyssynchrony. Arq Bras Cardiol. 2018;111(4):616-7. https://doi.org/10.5935/abc.20180200

18. Leyva F, Nisam S, Auricchio A. 20 years of cardiac resynchronization therapy. JACC. 2014;64(10):1047-58. https:// doi.org/10.1016/j.jacc.2014.06.1178

19. Papelbaum B. Galvão Filho SS, Vasconcelos JTM, Duarte CE, Chiarini R Numata BK, et al. Punção do óstio do seio coronariano ocluído para implante de eletrodo ventricular esquerdo: uma nova alternativa. Rev Soc Cardiol Estado de São Paulo. 2018;28(4):489-91. https://doi.org/10.29381/01038559/20182804489-91

20. Nascimento EA, Wiefels Reis CC, Ribeiro FB, Alves CR, Silva EN, Ribeiro ML, et al. Relação entre dissincronismo elétrico e mecânico em pacientes Submetidos a TRC com implante do eletrodo de VE orientado pela cintilografia GATED SPECT. Arq Bras Cardiol. 2018;111(4):607-15. https://doi.org/10.5935/ abc.20180159

21. Birnie et al. Incidence of AF with adaptive CR. Heart Rhythm. 2017;14(12). https://doi.org/10.1016/j.hrthm.2017.08.017

22. Linde C, Abraham WT, Gold MR, Daubert JC, Tang ASL, Young JB, et al. Predictors of CRT clinical response. Eur J Heart Failure. 2017:19(8):1056-63. https://doi.org/10.1002/ejhf.795

23. Melo CS, Silva Júnior LM, Vazquez BP, Oliveira JC, Salerno HD, Lage JS. Evidências atuais para indicação da terapia de ressincronização cardíaca. Relampa. 2013;26(3):151-61.

24. Rocha EA, Pereira FTM, Quidute ARP, Abreu JS, Lima JWO, Sobrinho CRMR, et al. Quem são os super-respondedores à ressincronização. Int J Cardiovasc Sci. 2017;30(1):61-9. https:// doi.org/10.5935/2359-4802.20170020

25. Hsu JC, Solomon SD, Bourgoun M, McNitt S, Goldenberg I, Klein $\mathrm{H}$, et al; MADIT-CRT Executive Committee. Predictors of super-response to cardiac resynchronization therapy and associated improvement in clinical outcome: the MADIT-CRT (multicenter automatic defibrillator implantation trial with cardiac resynchronization therapy) study. J Am Coll Cardiol. 2012;59(25):2366-73. https://doi.org/10.1016/j.jacc.2012.01.065. 